\title{
Effects of Soil Substrate on the Ecological Features of the Sand Pit- building Antlions Myrmeleon formicarius Linnaeus, 1767 (Neuroptera: Myrmeleontidae) Larvae in the Amanos Mountains of Turkey
}

\author{
Sadreddin TUSUN*,1, Hakan BOZDOĞAN²
}

\begin{abstract}
${ }^{1}$ Faculty of Ziya Gökalp Education, Department of Biology, University of Dicle, 21280, Diyarbakır, Turkey
${ }^{2}$ Department of Herbal and Animal Production, Vocational School of Technical Sciences, University of Kırşehir Ahi Evran, 40100, Kırşehir, Turkey ORCID ID: Sadreddin TUSUN: https://orcid.org/0000-0002-0696-4244; Hakan BOZDOGAN: $\underline{\text { https://orcid.org/0000-0002-6836-4383 }}$
\end{abstract}

\begin{abstract}
Received: 21.08 .2020
Accepted: 30.09 .2020

Published online: 14.10 .2020

Issue published: 31.12 .2020

Abstract: The hunting behavior of antlion larvae is unique in the insect world and the soil characteristics may strongly affect their microhabitat selection. Therefore, the substrate type of sand pit construction is expected to have an important role in their traps. Different types of soil substrates can be inhabited by Myrmeleon formicarius Linnaeus, 1767 larvae. This study was conducted during 2018-2019 June-August in the Amanos Mountains of Turkey to examine the relationship between the microhabitat preference of larvae of M. formicarius. In this study, five substrate types were determined as particularly according to their habitat preference. In this study, the preference of fine-grained soils is found more adaptive because the pits are constructed in these substrates are more functional for longer periods and they are much more successful in trapping their prey than the coarse-grained soil pits. Furthermore, it was found that there is a direct relationship between the pit size and substrate particle structure. Therefore, the detection and selection of microhabitats under more convenient ecological conditions, which increase capture success and elucidate the hunting strategy, may be carried out during strong soil substrate selection for Myrmeleon Linnaeus species. It was concluded that there is no strong relationship between the soil substrate type, $\mathrm{pH}$, and trap diameter.
\end{abstract}

Keywords: Neuroptera, Myrmeleon, sand pit building, ecology.

\section{Toprak Substratının Amanos Dağları'nda Kumul Yuva Yapan Myrmeleon formicarius Linnaeus, 1767 (Neuroptera: Myrmeleontidae) Larvasının Ekolojik Özelikleri Etkisi}

Öz: Karıncaaslanı larvalarının avlanma davranışı böcekler dünyasında eşsiz bir yere sahiptir ve toprak karakterizasyonu bu canlıların microhabitat seçimlerinde güçlü bir etkiye sahip olabilmektedir. Bu nedenle, konik-kumul tuzağın substrat yapısının tuzak inşasında önemli bir rolü vardır. Myrmeleon formicarius Linnaeus, 1767, farklı toprak substratlarında konuşlanabilmektedir. Bu çalışma, 2018-2019 Haziran-Ağustos ayları arasında, M. formicarius larvasının türünün toprak substratı ile microhabitat seçimi arasındaki ilişkiyi göstermek üzere Amanos Dağları'nda yürütülmüştür. Çalışma kapsamında habitat tercihlerine göre 5 substrat tipi tanımlanmıştır. Çalışmada, larvalarının yuva yapımında iyi elenmiş toprak partiküllerini tercih ettiği saptanmıştır. Zira bu tip topraklarda, kalın-kaba partiküllü topraklara oranla avlanma başarıları daha yüksek ve daha fonksiyonel olmaktadır. Dahası, yuva yarıçapı ile partikül yapısı arasında direkt bir ilişki bulunmaktadır. Bu nedenle Myrmeleon Linnaeus cins için uygun ekolojik koşullar altında avlanma başarı ve stratejisinde toprak türü seçimi önemli olabilmektedir. Çalışma sonucunda, toprak substrat tipi ve $\mathrm{pH}$ ile yuva yarıçapı arasında herhangi bir ilişkinin olmadığı saptanmıştır.

Anahtar kelimeler: Neuroptera, Myrmeleon, kumul yuva yapımı, ekoloji.

\section{Introduction}

The use of traps to aid the capture of prey was observed in a wide range of animal groups including insects (Alcock, 1972; Hansell, 1984). The ecological and ethological aspects of animal capture have received a great deal of attention (Griffiths, 1980). As an important function of the trap is to improve the catch efficiency, animals must design traps in such a way to maximize the probability of capturing their prey (Lucas, 1989). Most animal traps are made from self-secreting silk; therefore, antlions are rare among trap builders because they use only materials found in the environment (Franks, Worley, Falkenberg, Sendova-Franks, \& Christensen, 2019).

The inverted conical pits are built by antlion larvae on the sand surface for capturing their prey (Devetak, Mencinger-Vračko, Špernjak, \& Devetak, 2007). Antlion larvae (Neuroptera: Myrmeleontidae) are predators of small arthropods that are sitting and waiting after digging pits in loose soil in order to capture their prays to fall into funnel-shaped traps. After a victim falls into the pit, the larva attempts to capture it and inserts its mandibles. They tend to position their pits far enough from those of other antlions in mostly dry, shaded, and sandy areas in order to ensure that an optimal number of prey fall in. These larvae are commonly known as antlions since the most common arthropod in the pit traps is ants (Devetak et al., 2007). Antlion larvae can be discriminated in different particle sizes of different soil substrates (Farji-Brener, 2003; Levente, 2006; Devetak, 2008; Hollis, Cogswell, Snyder, Guillette, \& Nowbahari, 2011; Devetak, Novak, \& Janžekovič, 2012; Devetak, Podlesnik, Klokocovnik, \& Janzekovic, 2013; Krivokhatsky, Shapoval, \& Shapoval, 2014; Devetak \& Arnett, 2015). Many ecologists have claimed that predation and climate have important effects on the 
population (Price, 1997). It is known that abiotic and biotic variables may interact, affecting populations through indirect effects. Several studies have shown that abiotic factors, such as soil moisture, litterfall abundance, temperature, rainfall, and soil compactness, may restrict the habitat available to antlions (Farji-Brener, 2003). Considering the hunting behavior of antlion larvae, microhabitat selection may be strongly influenced by soil characteristics (Gotelli, 1993). However, the construction of a pit in a suitable environment - where temperature, space between other pits, sand particle size, rainfall amount, and light-dark cycle are optimal - rather than an area where there are many preys is more important for antlions (Arnett \& Gotelli, 2001).

The spatial distribution of the antlion larvae has been reported as strongly influenced by abiotic environmental factors such as physical disturbance and degree of soil dryness (Matsura, Yamaga, \& Itoh, 2005). All living things require minimum amounts of certain essential elements with known biological roles and functions to maintain optimal health and productivity.

Soil can be ecological crossroad in terms of disposing of undesirable materials but also it is a transmitter of many contaminant chemicals as metals to surface-groundwater for living organisms (Giannakopoulou, Gasparatos, Haidouti, \& Massas, 2012).

The presence of adequate amounts of minerals such as $\mathrm{K}, \mathrm{Ca}, \mathrm{Mg}$, and $\mathrm{Fe}$ in the soil is partly dependent on the soil type and conditions.

The present study aims to investigate the soil substrate preferences of the pit- building antlion larvae M. formicarius that live in the Amanos Mountains of Turkey.

\section{Material and Methods}

\subsection{Study Area}

The Amanos Mountains draw attention because of its extraordinary natural heritage. These Mountains are located in the Mediterranean Region and they are one of the most intact areas of Turkey. This chain of mountains has very important natural areas with its flora, fauna diversity, and its sensitive ecosystems (Aytaç \& Semenderoğlu, 2012). It has got 1580 plant taxa and 251 of which are endemic for Turkey (Baba \& Doğan, 2018). It also contains so many plant taxa according to Mediterranean, Euro-Siberian, Irano-Turanian, and Cosmopolitan phytogeographical regions (Türkmen \& Düzenli, 1998). In terms of genetic resources, mountain ecosystems have numerous important species, and, particularly, the mountains of Turkey have many endemic herbaceous species of the Anatolian Region (Türkmen, 2018).

\subsection{Method}

This study was carried out between June and August 2018 on the Amanos Mountains of Turkey. We collected soil samples around the zones to experimentally assess the relationship between the microhabitat preference of larvae and soil substrate types. To determine the direct and indirect effects of soil structure on the abundance of M. formicarius, we randomly established 8 plots as localities. All specimens were identified in the species level by Dr. Ali Satar at Dicle University in accordance with Badano and Pantaleoni (2014).

We classified them into four groups in terms of the locality types as in Figure 1. After sieving dry substrate samples, the collected substrate particle sizes were determined according to Devetak, Špernjak, and Janžekovič (2005). The mean annual rainfall was 1600 $2100 \mathrm{~mm}$ and the mean annual temperature was $27^{\circ} \mathrm{C}$ in the survey area. Soil structure was classified based on its percentage of soil particles with different sizes $(<2 \mathrm{~mm}$ to $>5 \mathrm{~mm}$ ). Each larva was put on the substrate with large particles. At each locality, the area of dense antlion pits was circumscribed and measured (Fig. 2). Pitfall trapping was conducted on 10 dates $\left(6^{\text {th }}, 10^{\text {th }}, 16^{\text {th }}, 20^{\text {th }}\right.$, and $28^{\text {th }}$ June 2018 and $10^{\text {th }}, 12^{\text {th }}, 18^{\text {th }}, 22^{\text {nd }}$, and $26^{\text {th }}$ August 2019) at each of the 8 study plots. Soil samples were collected in a depth of approximately $0-25 \mathrm{~cm}$. These were dried at $110^{\circ} \mathrm{C}$, ground to pass through a 200 -mesh sieve, and transferred to polyethylene bottles. The dried samples were ground to fine powder; then, the powdered samples were sieved using a standard set of sieves to diameter. Every powdered sample was shacked using an electric shaker to make sure that the sample was homogenized (El-Taher \& Abdelhalim, 2014). The $\mathrm{pH}$ values of the soil samples were determined in a soil/water (1:2.5) suspension with a digital $\mathrm{pH}$-meter.

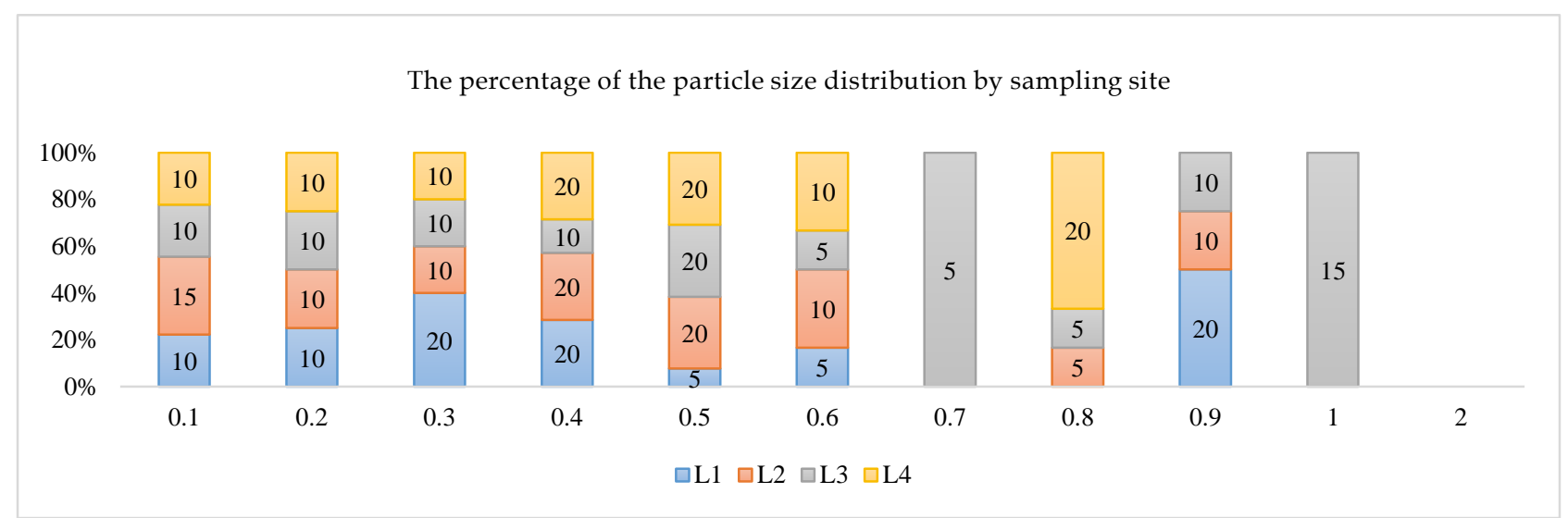

Figure 1. Particle size distribution in the different habitat types in the Amanos Mountains. L1: Locality type 1, L2: Locality type 2, L3: Locality type 3, L4: Locality type 4 


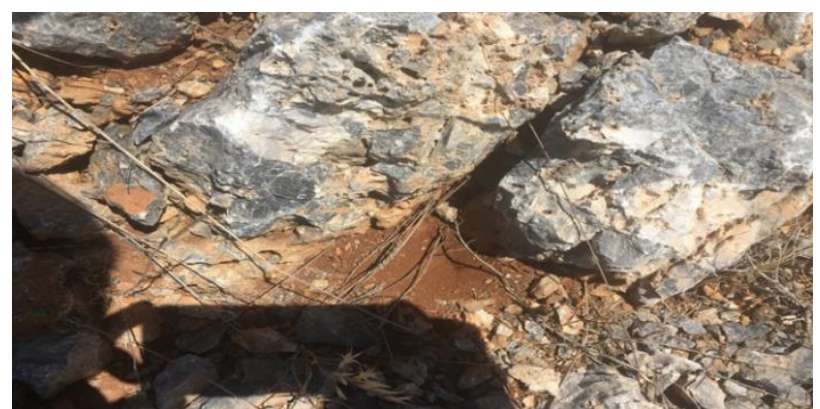

Figure 2. Different soil substrate in survey areas

\section{Results}

In this study, 8 locality types listed below were observed and examined. Eight sand traps have been examined in each locality labeled as Loc A, B, C, D, E, F, G, H in Table 1. The distances to the nearest ant nest have been measured as min. 2900 and max. $12450 \mathrm{~mm}$ in the survey area. Four north and just one southwest direction pit trap showed in Table 2 were observed. Therefore, no soil particle size was bigger than $1.0 \mathrm{~mm}$. Al, Si, K, Fe, Mn, $\mathrm{Cu}$, Se, and $\mathrm{Ni}$ elements have been observed in normal levels symbolized as N. pH levels ranged from 4.2 to 6.1 in the different soil substrates.

\section{Discussion}

It was hypothesized by Devetak et al. (2012) that antlions larvae may be distinguished as their substrate type choice. Furthermore, pit diameter, pit depth, and pit angle of Euroleon nostras were determined to decrease significantly with substrate density. The effects of substrate density on site selection and pit characteristics were thoroughly investigated for the first time in their study. They concluded that antlions occupy places with different substrate densities varying from 121 to $1562 \mathrm{~g} / 1$ in natural habitats. Furthermore, they stated that the higher was the substrate density, the lower were the pit diameter, pit depth, and pit angle when E. nostras larvae were forced to construct a pit in each of the eightsubstrate densities (i.e., no-choice experiment).

Devetak et al. (2007) emphasized that the number of pits and the pit diameter depend on substrates with certain particle sizes. The most convenient substrate for capturing prey and forming pit is sand having a particle size of $0.23-0.54 \mathrm{~mm}$.

Devetak and Arnett (2015) revealed that the composition of substrates in natural habitats and the effect of substrate particle size on-site selection are important for sand-dwelling antlion and wormlion larvae.

Heinrich and Heinrich (1984) observed the entrances of ant nests in the midst of patches of sand and they implied that there is a strong relationship between the antlions' sands and the locations of an ant nest.

Luna (1988) stated that organic soil fertility practices can provide supplies of secondary and trace elements, occasionally lacking in conventional farming systems that rely primarily on artificial sources of $\mathrm{N}, \mathrm{P}$, and $\mathrm{K}$. Besides nutrient concentrations, optimum fertilization, which provides a proper balance of elements, can stimulate resistance to insect attack.

Table 1. The relationship between the soil substrate type, $\mathrm{pH}$ and trap diameter

\begin{tabular}{|c|c|c|c|c|c|c|c|c|c|c|c|}
\hline \multirow{2}{*}{$\begin{array}{l}\text { Number of } \\
\text { Locality Type }\end{array}$} & \multirow{2}{*}{ Type of Soil Substrate } & \multirow{2}{*}{$\mathrm{pH}$} & \multirow{2}{*}{$\begin{array}{l}\text { Trap diameter } \\
(\mathrm{mm})\end{array}$} & \multicolumn{8}{|c|}{ Soil Elements } \\
\hline & & & & $\mathrm{Al}$ & $\mathrm{Si}$ & K & $\mathrm{Fe}$ & $\mathrm{Mn}$ & $\mathrm{Cu}$ & Se & $\mathrm{Ni}$ \\
\hline LocA & Fine gravel & 5.4 & $8-17$ & $\mathrm{~N}$ & $\mathrm{~L}$ & $\mathrm{~N}$ & $\mathrm{~N}$ & $\mathrm{~N}$ & $\mathrm{~N}$ & $\mathrm{~L}$ & $\mathrm{~L}$ \\
\hline LocB & Dark Brown Forest Soil & 5.1 & $9-14$ & $\mathrm{~N}$ & $\mathrm{~L}$ & $\mathrm{I}$ & I & I & $\mathrm{N}$ & $\mathrm{L}$ & $\mathrm{L}$ \\
\hline LocC & Laterite & 4.4 & $11-18$ & $\mathrm{~N}$ & $\mathrm{~L}$ & $\mathrm{~L}$ & $\mathrm{~N}$ & $\mathrm{~N}$ & $\mathrm{~N}$ & $\mathrm{~L}$ & I \\
\hline LocD & Topsoil & 4.2 & $7-15$ & $\mathrm{~N}$ & $\mathrm{~N}$ & $\mathrm{~N}$ & I & $\mathrm{N}$ & $\mathrm{N}$ & $\mathrm{N}$ & I \\
\hline LocE & Laterite & 5.0 & $11-19$ & $\mathrm{~N}$ & I & $\mathrm{N}$ & I & $\mathrm{N}$ & $\mathrm{N}$ & $\mathrm{N}$ & $\mathrm{N}$ \\
\hline LocF & Humic & 6.1 & $6-14$ & $\mathrm{~L}$ & I & $\mathrm{N}$ & $\mathrm{N}$ & $\mathrm{N}$ & $\mathrm{L}$ & I & $\mathrm{L}$ \\
\hline LocG & Silt & 5.5 & $10-15$ & $\mathrm{~N}$ & I & $\mathrm{N}$ & $\mathrm{N}$ & $\mathrm{N}$ & $\mathrm{L}$ & $\mathrm{L}$ & $\mathrm{L}$ \\
\hline LocH & Loamy sand & 5.9 & $21-26$ & I & $\mathrm{N}$ & $\mathrm{N}$ & $\mathrm{N}$ & $\mathrm{L}$ & I & $\mathrm{L}$ & $\mathrm{L}$ \\
\hline
\end{tabular}

L: Low, N: Normal, I: Intense, Loc: Localit

Table 2. Distance to the nearest ant nest $(\mathrm{mm})$ in the survey area.

\begin{tabular}{lll}
\hline Distance to the nearest ant nest $(\mathrm{mm})$ & The direction of Ant nest to the trap & Number of Locality \\
\hline 3000 & North & L1 (Pit Trap Loc1B) \\
5400 & North (Pit Trap Loc2D) & L3 (Pit Trap Loc3H) \\
2900 & South & L4 (Pit Trap Loc4C) \\
3850 & East & L3 (Pit Trap Loc3E) \\
6000 & Southwest & L1 (Pit Trap Loc1F) \\
6500 & North & L4 (Pit Trap Loc4G) \\
12450 & North & L2 (Pit Trap Loc2A) \\
12000 & Northeast & \\
\hline
\end{tabular}

\section{References}

Alcock, J. (1972). The evolution of tools by feeding animals. Evolution, 26, 464-473. https://doi.org/10.1111/j.1558-5646.1972.tb01950.x

Arnett, A.E., \& Gotelli, N.J. (2001). Pit-building decision of larval ant lions: effect of larval age, temperature, food and population source. Journal of Insect Behavior, 14, 89-97. https://doi.org/10.1023/A:1007853730317

Aytaç, A.S., \& Semenderoğlu, A. (2012). Amanos Dağları'nın Orta Kesiminin, Doğa Koruma Kriterleri Açsından Degerlendirilmesi. Anadolu Dogă Bilimleri Dergisi (Journal of Anatolian Natural Sciences), 3(1), 1-14.

Baba, H., \& Doğan, Y. (2018). Investigation of Myxomycetes (Myxomycota) in South Amanos Mountains (Hatay-Turkey). Celal
Bayar University Journal of Science, 14(3), 277-284. https://doi.org/ $\underline{10.18466 / \text { cbayarfbe. } 423334}$

Badano, D., \& Pantaleoni, R.A. (2014). The larvae of European Myrmeleontidae (Neuroptera). Zootaxa, 3762(1), 1-71. https:/ / doi.org/ $\underline{10.11646 / \text { zootaxa.3762.1.1 }}$

Devetak, D., Špernjak, A., \& Janžekovič, F. (2005). Substrate particle size affects pit building decision and pit size in the antlion larvae Euroleon nostras (Neuroptera: Myrmeleontidae). Physiological Entomology, 30(2), 158-163. https://doi.org/10.1111/j.1365-3032.2005.00443.x

Devetak, D., Mencinger-Vračko, B., Špernjak, A., \& Devetak, M. (2007). Capture success in pit-building Antlion Euroleon nostras (Geoffroy in Fourcroy, 1785) (Neuroptera Myrmeleontidae) depends on the presence of pits, sand particle size and transmission of vibratory 
signals: a mini-review. Annali Museo Civico di Storia Naturale Ferrara, 8, 161-165.

Devetak, D. (2008). Wormlion Vermileo vermileo (L.) (Diptera: Vermileonidae) in Slovenia and Croatia. In Annale Series Historia Naturalis, 18, 283-286.

Devetak, D., Novak, T., \& Janžekovič, F. (2012). Effect of substrate density on behaviour of antlion larvae (Neuroptera: Myrmeleontidae). Acta Oecologica, 43, 1-7. http://doi.org/10.1016/i.actao.2012.05.010

Devetak, D., Podlesnik, J., Klokocovnik, V., \& Janzekovic, F. (2013). Antlions (Insecta: Neuroptera: Myrmeleontidae) of Albania. Turkish Journal of Zoology, 37, 362-366. https://doi.org/10.3906/zoo-1209-23

Devetak, D., \& Arnett, A.E. (2015). Preference of antlion and wormlion larvae (Neuroptera: Myrmeleontidae; Diptera: Vermileonidae) for substrates according to substrate particle sizes. European Journal of Entomology, 112(3), 500-509. https://doi.org/10.14411/eje.2015.052

El-Taher, A., \& Abdelhalim, M.A.K. (2014). Elemental analysis of soils from Toshki by using instrumental neutron activation analysis techniques. Journal of Radio Analytical and Nuclear Chemistry, 300(1), 431-435. https://doi.org/10.1007/s10967-014-2979-3

Farji-Brener, G.A. (2003). Microhabitat Selection by Antlion larvae Myrmeleon crudelis: Effect of Soil Particle Size on Pit-Trap Design and Prey Capture. Journal of Insect Behavior, 16(6), 783-796.

Franks, N.R., Worley, A., Falkenberg, M., Sendova-Franks, A.B., \& Christensen, K. (2019). Digging the optimum pit: antlions, spirals and spontaneous stratification. Proceedings of the Royal Society B, 286(1899), 2019036. https://doi.org/10.1098/rspb.2019.0365

Giannakopoulou, F., Gasparatos, D., Haidouti, C., \& Massas, I. (2012). Sorption behavior of Cesium in two Greek soils: Effects of Cs initial concentration, clay mineralogy and particle size fraction. Soil and Sediment Contamination, 21(8), 937-950. https://doi.org/10.1080/ $\underline{15320383.2012 .714418}$

Gotelli, N. (1993). Ant lion zones: Causes of high-density predator aggregations. Ecology, 74(1), 226-237. https://doi.org/10.2307/ 1939517

Griffiths, D. (1980). The feeding biology of ant-lion larvae: prey capture, handling and utilization. The Journal of Animal Ecology, 49(1), 99-125. https://doi.org/10.2307/4279

Hansell, M.H. (1984). Animal Architecture and Building Behaviour. London, UK, Longman., 352 pp.

Heinrich, B., \& Heinrich, M.J. (1984). The pit-trapping foraging strategy of the ant lion, Myrmeleon immaculatus De Geer (Neuroptera: Myrmeleontidae). Behavioral Ecology and Sociobiology, 14(2), 151-160. https://doi.org/10.1007/BF00291906

Hollis, K.L., Cogswell, H., Snyder, K., Guillette, L.M., \& Nowbahari, E. (2011). Specialized Learning in Antlions (Neuroptera: Myrmeleontidae), Pit-Digging Predators, Shortens Vulnerable Larval Stage. Plos One, 6(4), 1-7. https://doi.org/10.1371/journal.pone. 0017958

Krivokhatsky, V.A., Shapoval, N.A., \& Shapoval, A.P. (2014). Antlions (Neuroptera, Myrmeleontidae) from ornithological traps on the Curonian Spit: A three-species community containing a new species., Entomological Review., 94, 605-612. https://doi.org/10.1134/ $\underline{\mathrm{S} 0013873814040137}$

Levente, A. (2006). Pit building antlion larvae effect to the distribution of the substrate particles in their microhabitats. Natura Somogyiensis, 9, 167-185.

Lucas, J.R. (1989). The structure and function of antlion pits: slope asymmetry and predator-prey interactions. Animal Behaviour, 38(2), 318-330. https://doi.org/10.1016/S0003-3472(89)80093-4

Luna, J.M. (1988). Influence of soil fertility practices on agricultural pests. In: Globalperspectives on Agroecology and Sustainable Agricultural Systems. Proceedings of the Sixth International Science Conference of IFOAM, Santa Cruz, CA, pp. 589-600.

Matsura, T., Yamaga, Y., \& Itoh, M. (2005). Substrate selection for pit making and oviposition in an antlion, Myrmeleon bore Tjeder, in terms of sand particle size. Entomological Science, 8(4), 347-353. https://doi.org/10.1111/j.1479-8298.2005.00134.x.

Price, P.W. (1997). Insect Ecology. New York, ABD, John \& Sons, 3rd ed., 874pp.

Türkmen, N. (2018). The plant diversity and conservation status of the Taurus and Amanos mountains in the Eastern Mediterranean Region of Turkey. Biodiversity Journal, 9(4), 385-394. https://doi.org/ 10.31396/Biodiv.Jour.2018.9.4.385.394

Türkmen, N., \& Düzenli, A. (1998). The flora of Dörtyol and Erzin district of Hatay Province in Turkey. Turkish Journal of Botany, 22(2), 121-142. 